\title{
Learners' Perspectives on Pure Science Content in Vocational Degree Programmes: Chemistry for Pharmacists
}

\author{
James R. Smith ${ }^{1}$ * Melleisha K. Chungh, Sara Sadouq, and Asarthan Kandiah \\ *School of Pharmacy and Biomedical Sciences, University of Portsmouth, United \\ Kingdom
}

\begin{abstract}
The objective of this study was to enquire how the chemistry experience of pharmacy students can be enhanced and how the virtual learning environment (VLE) for chemistry-related pharmacy modules might be improved. All MPharm students at the University of Portsmouth UK were asked to complete a project-designed online questionnaire. Data from University course module feedback questionnaires were also analysed. Qualitative and quantitative analyses were performed, using appropriate statistical evaluation. Pre-university chemistry was not correlated with current perceived relevance, difficulty or workload ( $p>0.05)$. The latter two were positively correlated $(p=0.003)$. Students realised their study of chemistry was important (89\%). Chemistryand biology-related areas were rated equally enjoyable ( $p>0.05)$, but less than pharmacy practice areas ( $p<0.0001)$. Students' preferred choices for VLE development were video lectures > VLE quizzes > audio content. Keeping chemistry content relevant on pharmacy programmes is important. Strategies for improving learning through extended use of the VLE have been identified.
\end{abstract}

Keywords: Pharmacy, Chemistry, MPharm, Higher education, Virtual learning environment (VLE)

\section{INTRODUCTION}

For a number of years, there have been concerns regarding the relevance of teaching chemistry to undergraduate pharmacy students (Alsharif et al., 1999; Faruk Khan et al., 2011; Roche et al., 2000; Roche \& Alsharif, 2002). The International Pharmaceutical Federation state "Basic (first degree) education programmes should provide pharmacy students and graduates with a sound and balanced grounding in the natural, pharmaceutical and healthcare sciences that provide the essential foundation for pharmacy practice in a multi-professional healthcare delivery environment" (Prescott et al., 2014, p. 2). In the United Kingdom (UK), over the past decade, the General Pharmaceutical Council ( $\mathrm{GPhC})$, the pharmacy independent regulator, has placed greater emphasis on clinical and practice-based subjects, with more fundamental science-based subjects being increasingly integrated (General Pharmaceutical Council, 2014; Jesson et al., 2006). Anecdotally, student engagement and satisfaction with more chemistry-related areas of the Master of Pharmacy (MPharm) curriculum sometimes appears to be lower than for professional practice elements. If true, this might be due to a combination of factors, such as not being able to appreciate underlying principles in pharmaceutical science, finding chemistry difficult or having had a negative past experience of the subject.

\footnotetext{
${ }^{1}$ Corresponding author: james.smith@port.ac.uk
} 
The aim of this paper was to gain MPharm students' perspectives into how they thought their chemistry experience could be enhanced, and how the virtual learning environment (VLE; also known as learning management system) for chemistry-related pharmacy modules could be improved. Pre-university chemistry experiences and current perceptions were also investigated. These data should provide a useful resource for educators in pharmacy to improve chemistry-related learning experiences and to make them relevant, engaging and enjoyable for students. Research outcomes should be used in conjunction with evidence-based practices that have emerged from numerous metastudy analyses, which link teaching and learning approaches to achievement (Hattie, 2009).

\section{METHODOLOGY}

The research was carried out in accordance with the procedures outlined by the University of Portsmouth Research Ethics Committee.

\section{Main questionnaire}

An online questionnaire (Survey Planet) consisting of 20 questions (different types; Table 1) was formulated for all students (years 1-4) across the MPharm course at the University of Portsmouth, UK. The online design was thought to maximise the return and allow time for more considered responses. The project was undertaken in the form of an MPharm fourth-year project. Students were separately emailed the weblink and asked to take part in the survey via a blind bcc: opening email stating:

I am a fourth-year pharmacy student carrying out a chemistry educationbased project looking at 'How the chemistry experience of pharmacy undergraduate students can be enhanced' \& 'How Moodle can be improved for chemistry-related modules'. This questionnaire has been designed to find out about the way you perceive how chemistry is taught and views on some ideas. Answers provided will be anonymous and treated confidentially.

As an incentive, a chance to win Amazon vouchers (£20) was offered, provided email addresses were supplied. The questionnaire was made available to students between December 2013 and January 2014. Responding students were allocated numbers so that responses to different questions could be cross-matched/compared. Interviews and the thoughts of lecturers were not investigated in this preliminary study. Statistics were performed using one-way ANOVA (conditions for parametric tests were satisfied independence, normality and homogeneity of variance) together with Tukey-post hoc testing $(\alpha=0.05)$. Where correlational analysis was required, the Spearman rank correlation $\left(r_{s}\right.$, ordinal, ranked data) was used. Student questionnaires were analysed using SPSS (Version 22, IBM, NY, USA). Q numbers throughout the text refer to question numbers in this main questionnaire.

The questionnaire generated 122 student responses: $23.9 \%$ of the possible 510 total (Q1; Table 2). Progressively higher responses were obtained from each successive year group (e.g., 13 and $41 \%$ for years 1 and 4; Table 2). 
Table 1. Main questionnaire questions and answer choices.

\begin{tabular}{|c|c|}
\hline $\begin{array}{l}\text { Question } \\
\text { No. }\end{array}$ & Question / Answers \\
\hline 1 & Which year of Pharmacy are you studying in? [1st][2nd][3rd][4th] \\
\hline 2 & $\begin{array}{l}\text { Which devices do you have? (Please tick the ones that apply to you) [Mobile][Laptop/netbook][Tablet][I } \\
\text { do not own any devices][Other (please specify)] }\end{array}$ \\
\hline 3 & Concerning Q2, which devices do you use to access Moodle? [blank] \\
\hline 4 & What A/AS-level chemistry grade did you achieve? [blank] \\
\hline 5 & $\begin{array}{l}\text { What syllabus board did you study A/AS-level chemistry? Please tick. [OCR (standard OCR)][OCR } \\
\text { (Salters syllabus)][Edexcel (standard)][Edexcel (Nuffield)][AQA][WJEC][CCEA (Northern } \\
\text { Ireland)][Scottish Qualification Authority (SQA)][Cambridge International Examinations (CIE, } \\
\text { International students)][International Baccalaureate][Other (please specify)] }\end{array}$ \\
\hline 6 & $\begin{array}{l}\text { Approximately, how many lab experiments did you do on your A/AS-level chemistry course? } \\
{[0][1][2][3] \ldots . .[29][30]}\end{array}$ \\
\hline 7 & Is the study of chemistry important for a pharmacist? [Yes][No] \\
\hline 8 & If Yes to Q7, in what way? [blank] \\
\hline 9 & $\begin{array}{l}\text { Of the units you have so far started or completed, please rank the following units in order of your } \\
\text { enjoyment of them (1-favourite, to 6-least favourite, for your year): }\{1 \text { st Years [Pharmaceutical } \\
\text { chemistry][Introduction to formulation][Introduction to neuroscience \& pharmacology][Cells to } \\
\text { systems][Developing life-long learning for pharmacy][Introduction to pharmacy practice] }\}\{2 \text { nd Years } \\
\text { [Drug development \& formulation][Neurosciences, endocrine \& gastrointestinal pharmacology \& } \\
\text { therapeutics][Immunology \& microbiology in health and disease][Respiratory, renal \& cardiovascular } \\
\text { pharmacology \& therapeutics][Medicines patients \& public health] }\}\{3 \text { rd Years [Pharmacology \& } \\
\text { therapeutics } 3][\text { Pharmaceutical formulation][Clinical pharmacy \& secondary care][Natural products a } \\
\text { source of medicines][Community \& primary care pharmacy][Pharmacy research methods]\}\{4th Year } \\
\text { [Design \& advanced delivery of drugs][Pharmacy project][Medicines management in } \\
\text { practice][Pharmacology \& therapeutics } 4])\end{array}$ \\
\hline 10 & $\begin{array}{l}\text { What chemistry topics that you have studied so far on the MPharm do/did you find the least interesting? } \\
\text { [blank] }\end{array}$ \\
\hline 11 & $\begin{array}{l}\text { Please mark the following statements with 1-strongly agree, 2-agree, 3-neutral, 4-disagree \& 5-strongly } \\
\text { disagree: A: In chemistry-related units, the workload is greater than in other units [1][2][3][4][5]; B: } \\
\text { There should be more chemistry-related practicals [1][2][3][4][5]; C: I find chemistry-related units } \\
\text { difficult [1][2][3][4][5]; D: I don't see the point in studying chemistry on an MPharm degree. } \\
{[1][2][3][4][5]}\end{array}$ \\
\hline 12 & $\begin{array}{l}\text { Rank the following ideas with } 1 \text { as top and } 10 \text { as least favourite choice: Website of some sort linked to } \\
\text { Moodle; More links on Moodle with YouTube clips showing lab practicals; Help from students from } \\
\text { previous years; Blog for students to ask each other questions about chemistry-related course content; } \\
\text { Chat rooms on Moodle; Quizzes with questions and answers on Moodle; Pre-lecture quiz/pre-lecture } \\
\text { recap of previous lecture; Sum-up of the lecture with a few questions; Short audio clips on Moodle with } \\
\text { recap points of the lecture/areas people found difficult identified by students emailing lecturers; } \\
\text { Complete videos of lectures on Moodle [1 to } 10 \text { sequence for each] }\end{array}$ \\
\hline 13 & Please explain your preferred choice in Q12? [blank] \\
\hline 14 & $\begin{array}{l}\text { What are your opinions on lab classes? Please tick the most relevant boxes that apply to you. Chemistry- } \\
\text { related practicals... [give a better learning experience than just lectures][are boring][are just about } \\
\text { right][would be better replaced with lab technique videos][are difficult][are rushed][get me stressed] }\end{array}$ \\
\hline 15 & Which e-learning resources would aid your learning in chemistry? [blank] \\
\hline 16 & $\begin{array}{l}\text { If videos of lab techniques were uploaded to Moodle, which topics/techniques would you like to see? } \\
\text { (Please name a few) [blank] }\end{array}$ \\
\hline 17 & $\begin{array}{l}\text { Excluding practicals, would you prefer to: [A: have all/majority of lectures as video lectures where you } \\
\text { can download/watch at your own pace and convenience?][B: follow a more 'traditional' style of learning } \\
\text { (ie, coming to lectures)?] }\end{array}$ \\
\hline 18 & $\begin{array}{l}\text { Tick the following statement regarding the use of TurningPoint that is most relevant to you... [A: It } \\
\text { should be used more][B: it's annoying][C: it doesn't help me learn][D: It's a useful tool for checking my } \\
\text { understanding] }\end{array}$ \\
\hline 19 & $\begin{array}{l}\text { Students sometimes say they 'want more feedback'. If this applies to you, what specifically would be } \\
\text { useful? [blank] }\end{array}$ \\
\hline 20 & Any other comments/suggestions? [blank] \\
\hline
\end{tabular}




\section{Formal feedback surveys}

This university collects student feedback surveys from students on all study units across the university on all its courses to provide formal evaluation (in addition to those data that individual lecturers may collect for their own evaluation). A traffic light system is used as a quality symbol to highlight whether the mean value in any of the performance indicators / responses to questions (Table 3) is below the quality to guideline (red), within the range of tolerance (amber) or within the quality guideline (green). Here, in addition to the 'main questionnaire' (Table 1), student enjoyment scores were also extracted from the completed student feedback surveys relating to all pharmacy units being studied on each of the four MPharm degree years (dated April 2013). Some unit titles and content were different to that of the main questionnaire dataset (Table 1) due to the course being mid-way through a period of 'integration' to start to address separation of chemistry, biology and pharmacy practice areas. Statistics were carried out using one-way ANOVA and Tukey-post hoc testing ( $\alpha=0.05$; GraphPad Prism Version 6, GraphPad); ${ }^{*} p<0.05$, $* * p<0.01, * * * p<0.001, * * * * p<0.0001$.

Table 2. Main questionnaire responses by student year.

\begin{tabular}{cl}
\hline Question No. & Questionnaire statement \\
\hline 1 & The unit makes a positive contribution to my overall course \\
2 & I am clear about what I need to do to be successful in this unit. \\
3 & Lecturers are good at explaining things on this unit. \\
4 & Lecturers make this unit interesting. \\
5 & Lecturers are enthusiastic about what they are teaching on this unit. \\
7 & Lecturers' use of Virtual Learning Environment (Moodle) helped me to learn. \\
8 & I am able to communicate with lecturers teaching on this unit when I need to. \\
9 & The workload for this unit is manageable. \\
10 & I have had opportunities to get feedback on my work during this unit. \\
11 & Feedback on my work during this unit helped me clarify things I do not understand. \\
12 & The teaching rooms, laboratories, studios, or distance learning materials are of a \\
13 & good quality. \\
14 & I enjoyed this unit. \\
\hline
\end{tabular}

Table 3. Questions in the formal feedback survey (1=strongly disagree; $2=$ disagree; $3=$ neither agree nor disagree; $4=$ agree; $5=$ strongly agree).

\begin{tabular}{cccc}
\hline Student year & $\begin{array}{c}\text { Number of students who } \\
\text { answered the questionnaire and } \\
(\%)\end{array}$ & $\begin{array}{c}\text { Total number of } \\
\text { students per year }\end{array}$ & $\begin{array}{c}\text { \% of students who } \\
\text { answered the questionnaire }\end{array}$ \\
\hline 1 & $19(13)$ & 150 & 16 \\
2 & $17(14)$ & 120 & 14 \\
3 & $33(30)$ & 109 & 27 \\
4 & $53(41)$ & 131 & 43 \\
Total & $122(24)$ & 510 & 100 \\
\hline
\end{tabular}

\section{RESULTS AND DISCUSSION \\ Previous chemistry experience}

The first enquiry of the data (main questionnaire) concerned students' background education/experiences in chemistry prior to starting the MPharm. The modal average was General Certificate of Education Advanced/Advanced Subsidiary Level (GCE A/ASlevel; approximately equivalent to the Advanced Placement in the United States of America) grade B (range A-E). Although the spread included a fairly large positive skew ('right tail'), including a minor component (6\%) who had not studied the subject at this 
level (Table 4; Access to Higher Education (HE) courses are designed for students wishing to study for a degree, but whom do not have the usual university entry qualifications). The A/AS-level chemistry qualifications were awarded by a range of examination boards (Table 5); these data were recorded to inquire whether different syllabi might account for variations in the number of laboratory practical classes previously undertaken (and hence differences in currently observed laboratory competencies). Rather than checking the syllabi directly, students were asked to estimate the number of laboratory classes they thought they had attended during their A/AS-level course (Figure 1a). Again, there was quite a range of responses (mean $12 \pm 7$ ), although no significant difference between number of experiments and exam board/syllabus were observed (ANOVA, $F=0.823, p=0.584$; Figure $1 \mathrm{~b}$ ). Four students had not undertaken any experiments, three of whom had not completed A-levels (including 1 Access student).

Table 4. Pre-university qualification grades in chemistry (Q4).

\begin{tabular}{lc}
\hline A/AS-level chemistry grade & Number of students \\
\hline A $^{*}$ & 1 \\
A & 13 \\
B & 46 \\
C & 36 \\
D & 12 \\
Access to HE course & 7 \\
Did not study chemistry & 7 \\
Total & 122 \\
\hline
\end{tabular}

Table 5. Examination boards awarding A/AS-level chemistry studied by MPharm students before university (Q5).

\begin{tabular}{lc}
\hline Syllabus / exam board & Number of students \\
\hline OCR-Standard & 38 \\
OCR-Salters & 17 \\
Edexcel-Standard & 10 \\
Edexcel-Nuffield & 8 \\
AQA & 27 \\
WJEC & 3 \\
CCEA (Northern Ireland) & 0 \\
Scottish Qualifications Authority (SQA) & 0 \\
Cambridge International Examinations (CIE) & 2 \\
International Baccalaureate & 2 \\
Other & 15 \\
Total & 122 \\
\hline
\end{tabular}

\section{Perceived importance of chemistry for pharmacy students}

When asked whether the study of chemistry is important for pharmacy students (Q7), the majority of replies were Yes $(N=108,89 \%)$, in agreement with Prescott et al. $(47.2 \%$ chemistry very important, $42.9 \%$ important) (Prescott et al., 2014). The reasons stated for this (Q8) broadly fitted into the following categories: understanding the mode of drug action and how they work in the body $(N=33)$; important for understanding chemical reactions, properties and interactions $(N=24)$; fundamental to the degree $(N=23)$; not answered $(N=15)$; useful for industry $(N=11)$; not important $(N=8)$; for drug formulation $(N=4)$; for calculations $(N=2)$; and, an appreciation is needed, but not at such depth $(N=2)$. So, clearly meaningful connections of chemistry to pharmacy are seen as being very important. 
Figure 1. Student estimated number of chemistry laboratory experiments (a) performed during GCE A/ASlevels (Q6); and (b) compared to exam board/syllabus studied (Q5; exam board codes: 1-11=top to bottom, Table 5).

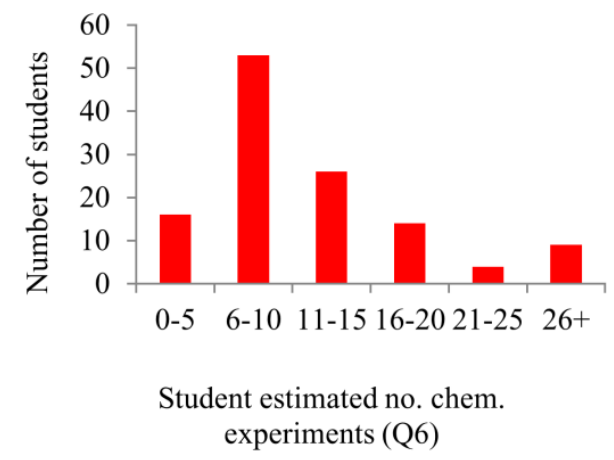

(a)

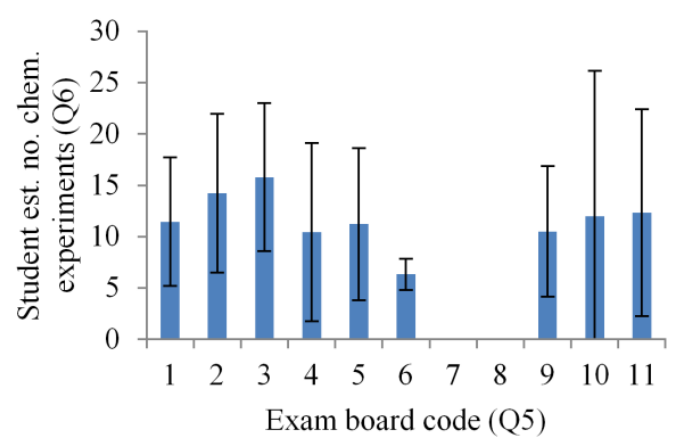

(b)

\section{Enjoyment of chemistry content}

The units of the MPharm course were classified, by the authors, as being either chemistry (1, Chem), biology (2, Biol), pharmacy practice (3, Pharm Pract) or other (4; e.g., study skills, and also the MPharm project due to large subject type variations). Thus, the classification coding for year $1=(1,1,2,2,4,3)$ year $2=(1,2,2,2,3)$, year $3=(2,1,3,1,3,4)$ and year $4=(1,4,3,2)$ for the respectively listed units in Table 1 (Q9). The 'enjoyment scores' ( $1=$ =most favourite, $6=$ least favourite; multiple values allowed; Q9, Table 1) were pooled for each of the subject-classified units (not 4, 'other') and \% subject enjoyment scores were calculated for each student. For example, if only year 4 data was provided and the input for Q9 $=(1,6,6,6)$, the $\%$ chemistry enjoyment score $=100 \%$. The data was not normalised with respect to the ratio of subject teaching, although this was approximately even for most answer combinations. Quite a few students $(N=52)$, not counting those from year 1 , only rated their current study year, and so the score was only based on the provided data. The mean \% enjoyment scores for Chem, Biol and Pharm Pract subjects were $23 \pm 13,41 \pm 16$ and $36 \pm 15(N=121)$, respectively; a significant difference (ANOVA, $F=48.005, p=3.305 \times 10^{-19}$ ) between Chem and Biol, and Chem and Pharm Pract $(p<0.001)$ was found, although no difference existed between Biol and Pharm Pract $(p=0.07)$. When the subject scores are plotted for each student (Figure 2), quite a range in individual preference can be observed.

To investigate these preferences further, enjoyment scores for Chem, Biol and Pharm Pract were extracted from the formal unit feedback surveys (Figure 3; for questions, see Table 3) and an ANOVA performed $(F=22.46, p<0.0001)$. As with the main questionnaire (Table 1), the enjoyment score for Chem $(3.52 \pm 0.93, N=253)$ was lower than for Pharm Pract (4.06 $\pm 0.74, N=210 ; p<0.0001$; Table 6), although not between Chem and Biol $(3.70 \pm 0.91, N=241, p>0.05)$ and a difference between Biol and Pharm Pract was also found with these data $(p<0.0001)$. The formal feedback responses also highlight that whilst these differences were seen, students scored a mean of $3.5 / 5$ for Chem, mid-way between the answers of neutral (3) and agree (4) to the statement 'I have found the learning activities enjoyable (on this unit)'. From these data, it would seem therefore that student enjoyment of chemistry units lags behind pharmacy practice, although was comparable to that in biology-based units. This trend was typical of many 
of the other performance indicators on the formal feedback survey, such as perceived positive contribution, interesting and enthusiastic lecturers, overall satisfaction and others (Figure 3; Table 6). This might be due to the perceived direct relevance of pharmacy practice for their future careers.

Figure 2. Student enjoyment of chemistry, biology and pharmacy practice-centred course units (Q9).

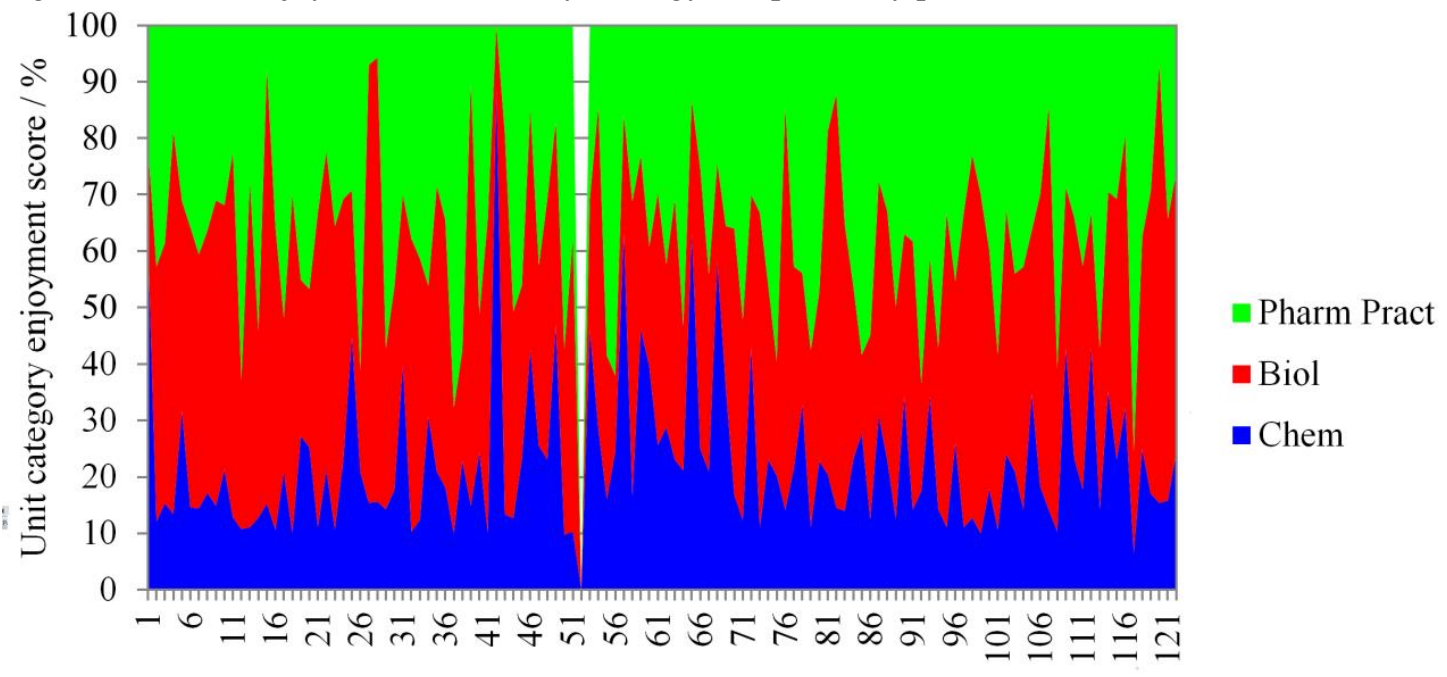

Student ID

Figure 3. Student responses from formal feedback surveys averaged per unit subject area $(\mathrm{N}=39-87,35-$ $67 \%$, depending on question; Apr 2013).

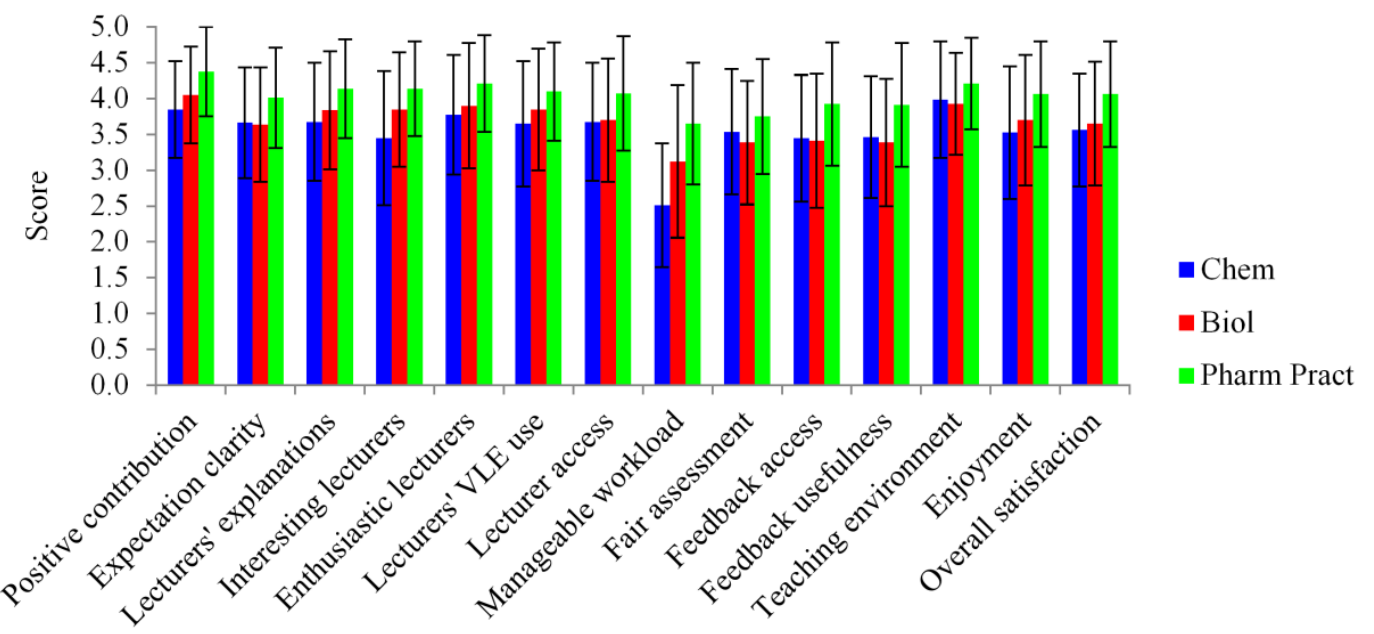

To investigate these preferences further, enjoyment scores for Chem, Biol and Pharm Pract were extracted from the formal unit feedback surveys (Figure 3; for questions, see Table 3) and an ANOVA performed $(F=22.46, p<0.0001)$. As with the main questionnaire (Table 1), the enjoyment score for Chem $(3.52 \pm 0.93, N=253)$ was lower than for Pharm Pract (4.06 $\pm 0.74, N=210 ; p<0.0001$; Table 6), although not between Chem and Biol $(3.70 \pm 0.91, N=241, p>0.05)$ and a difference between Biol and Pharm Pract was also found with these data $(p<0.0001)$. The formal feedback responses also highlight that whilst these differences were seen, students scored a mean of 3.5/5 for Chem, mid-way between the answers of neutral (3) and agree (4) to the statement 'I have 
found the learning activities enjoyable (on this unit)'. From these data, it would seem therefore that student enjoyment of chemistry units lags behind pharmacy practice, although was comparable to that in biology-based units. This trend was typical of many of the other performance indicators on the formal feedback survey, such as perceived positive contribution, interesting and enthusiastic lecturers, overall satisfaction and others (Figure 3; Table 6). This might be due to the perceived direct relevance of pharmacy practice for their future careers.

Table 6. Statistical differences in formal feedback data averaged per subject area (Fig. 3); NS=not statistically different $(p>0.05), * p<0.05, * * p<0.01, * * * p<0.001, * * * * p<0.0001$.

\begin{tabular}{lccc}
\hline Formal feedback & \multicolumn{3}{c}{ Subject comparison significance } \\
survey component & Chem \& Biol & Chem \& Pharm Pract & Biol \& Pharm Pract \\
\hline Positive contribution & $* *$ & $* * * *$ & $* * * *$ \\
Expectation clarity & $N S$ & $* * * *$ & $* * * *$ \\
Lecturers' explanations & $N S$ & $* * * *$ & $* * *$ \\
Interesting lecturers & $* * * *$ & $* * * *$ & $* * *$ \\
Enthusiastic lecturers & $N S$ & $* * * *$ & $* * *$ \\
Lecturers' VLE use & $*$ & $* * * *$ & $* * *$ \\
Lecturer access & $N S$ & $* * * *$ & $* * * *$ \\
Manageable workload & $* * * *$ & $* * * *$ & $* * * *$ \\
Fair assessment & $N S$ & $* * *$ & $* * * *$ \\
Feedback access & $N S$ & $* * * *$ & $* * * *$ \\
Feedback usefulness & $N S$ & $* * * *$ & $* * * *$ \\
Teaching environment & $N S$ & $* *$ & $* * * *$ \\
Enjoyment; & $N S$ & $* * * *$ & $* * *$ \\
Overall satisfaction & $N S$ & & \\
\hline
\end{tabular}

\section{Student perceived difficulty}

The responses to Q11 of the main questionnaire provided an overview and some interesting insights: importantly, chemistry units were seen to be quite difficult (although the workload was not too much of a burden), more chemistry practical lessons were desired and, again (see Q7, 8; Table 1), the importance of chemistry for pharmacy was emphasised (Figure 4). Positive correlations were found between perceived difficulty and 'seeing no point' in pharmacy students studying chemistry $\left(r_{s}=0.297, p=0.001\right)$, and between difficulty and workload $\left(r_{s}=0.271, p=0.003\right)$. A negative correlation existed between the desire for more laboratory practical sessions and seeing no point to the study of chemistry $\left(r_{s}=-0.195, p=0.031\right)$; no correlations were found between any of these four responses $(\mathrm{Q} 11)$ and pre-university chemistry experience $(\mathrm{Q} 4)(p>0.05)$.

Figure 4. Student views concerning chemistry in relation to other units studied on the course (Q11).
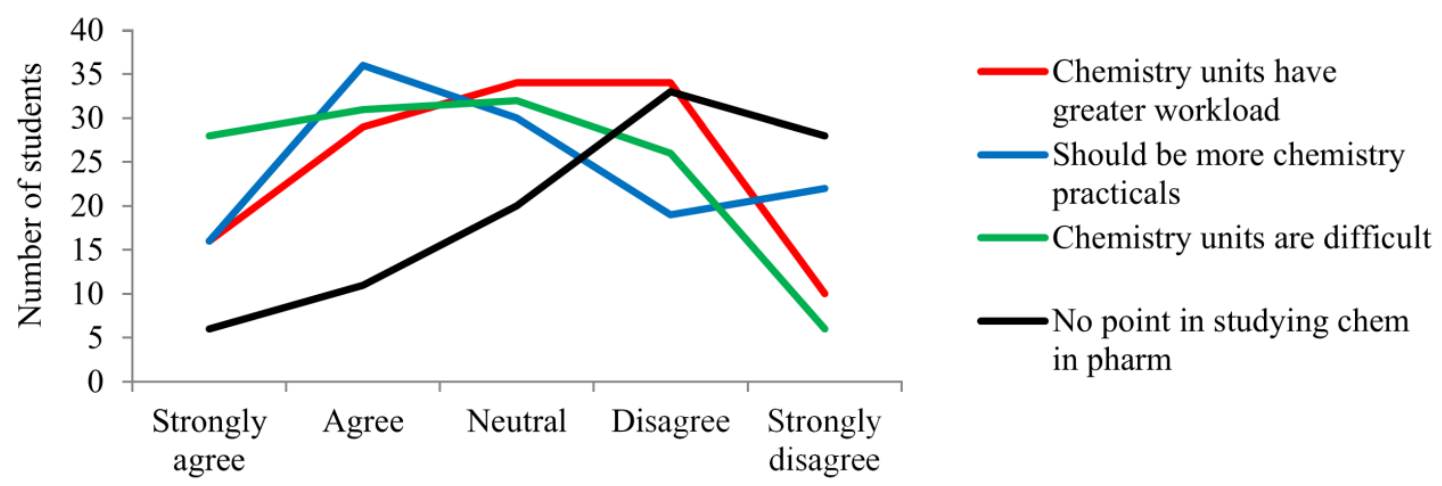


\section{Practical classes}

Regarding chemistry practical classes, students were asked to select from one or more from the words or phrases listed in Table 1 (Q14). The responses (more than one permitted per student) were: 'Give a better experience than just lectures' $(N=70 ; 57 \%)$, 'stressful' $(N=46 ; 38 \%)$, 'rushed' $(N=40 ; 33 \%)$, 'just about right' $(N=22 ; 18 \%)$, 'difficult' $(N=19 ; 16 \%)$, 'boring' $(N=15 ; 12 \%)$, and 'would be better replaced with laboratory technique videos' $(N=10 ; 8 \%)$. The latter category overlapped with 'stressed' in $60 \%$ of cases; 'just about right' did not overlap with 'rushed' or 'stressed' in $77 \%$ of cases. The level of stress, which is known to have a major influence on learning ability (Stokes \& Whiteside, 1984), might be associated with the fact that laboratory sessions are usually assessed (summative assessment), although information/guidance notes are presented to students well ahead of the sessions. The practicalities of performing more laboratory-based learning, possibly with less formal assessment, clearly need to be explored. The benefits of active and experiential learning are well documented as being best-practice (Chickering \& Gamson, 1987).

\section{Audience-response systems}

In addition to laboratory practical sessions, audience-response systems ('clickers') used in lectures provide a convenient method for promoting passive to active learners (BarthCohen et al., 2015; Cotes \& Cotua, 2014). TurningPoint has been used for a number of years on the MPharm course. Student views (Q18) concerning the use these devices were next investigated (Figure 5). Audience response systems are therefore clearly liked by the majority students who indicate that they help with their learning, especially when used as a formative assessment (Figure 5). More widespread use of this technology is also requested by students. Interestingly, the majority of students who said TurningPoint was 'annoying' or 'doesn't help me learn', were fourth year students $(80 \%$ and $82 \%$, respectively); combined, these unfavourable scores represent $54 \%$ of final year students.

Figure 5. Student views concerning the use of TurningPoint (Q18).

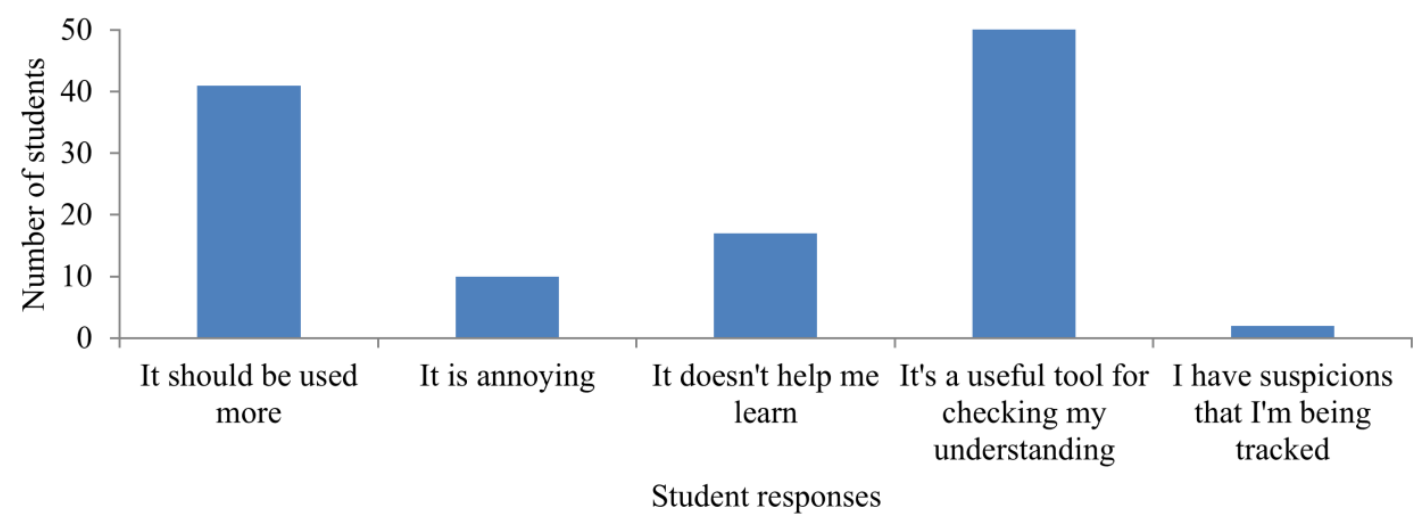

How can the VLE for chemistry-related modules for pharmacy students be improved? Technology continues to expand rapidly into the area of education. The VLE provides the obvious technology platform for MPharm students to continue their learning beyond the lecture theatre and laboratory. Moodle has been used for a number of years at the University of Portsmouth and staff members are continually learning how to best incorporate it into their teaching via blended learning (Bonk \& Graham, 2006). It was considered useful to survey the MPharm students to see which devices they are currently 
using generally (Table 7) and to access Moodle (Figure 6). Clearly, laptops and mobile (cell) phones are the main devices currently being used. For those students with laptops and phones, $51 \%$ used both devices to access Moodle. These results are useful in considering how the VLE might be used and what constraints and compatibility issues might be important. For example, content with pull-down menus would be inappropriate on a scrolling screen.

Table 7. Number of MPharm students using various electronic viewing devices (Q2).

\begin{tabular}{|c|c|c|}
\hline Device & Type & $\begin{array}{c}\text { Number of students using } \\
\text { device }\end{array}$ \\
\hline \multirow[t]{2}{*}{ Desktop Microsoft PC } & Owned by student & 8 \\
\hline & University owned & 15 \\
\hline \multirow[t]{2}{*}{ Desktop Macintosh } & Owned by student & 20 \\
\hline & University owned & 0 \\
\hline \multirow[t]{2}{*}{ Laptop } & Owned by student & 95 \\
\hline & University owned & 7 \\
\hline Netbook & & 2 \\
\hline \multirow[t]{8}{*}{ Tablet } & Apple & 29 \\
\hline & Blackberry & 1 \\
\hline & Microsoft & 2 \\
\hline & Samsung & 4 \\
\hline & Kindle/Kindle Fire & 4 \\
\hline & ASUS/Nexus 7/Google & 4 \\
\hline & Other & 1 \\
\hline & Do not use & 9 \\
\hline \multirow[t]{9}{*}{ Mobile (cell) phone } & iPhone & 53 \\
\hline & Blackberry & 8 \\
\hline & Nokia & 4 \\
\hline & LG & 0 \\
\hline & Samsung & 39 \\
\hline & HTC & 17 \\
\hline & Sony & 4 \\
\hline & Other & 2 \\
\hline & Do not use & 0 \\
\hline Other & & 5 \\
\hline
\end{tabular}

Figure 6. Number of MPharm students using various electronic devices to access Moodle (Q3).

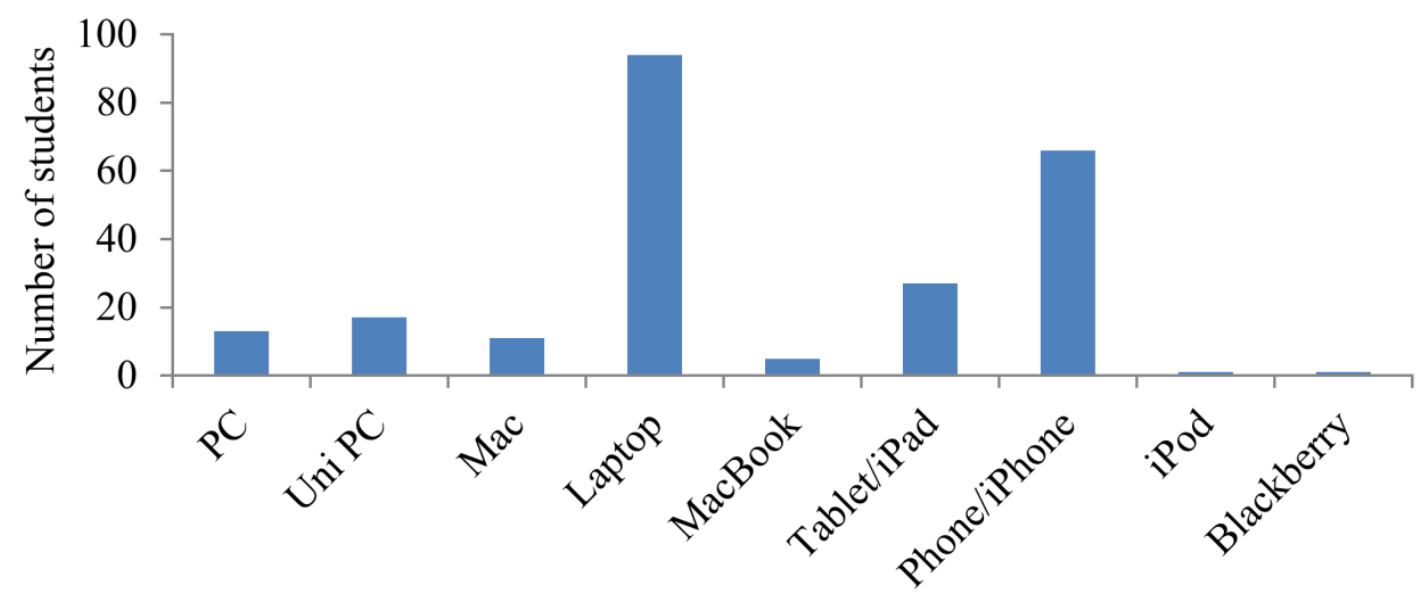

Device to access Moodle 
Q12 focused on ways in which MPharm students thought the VLE could be improved (Figure 7). Video lectures (type not specified) was the most frequent student first choice $(N=50)$, followed by audio clips $(N=39$; see Table $1 ; \mathrm{Q} 12)$ and Moodle quizzes $(N=38)$. The reasons for the student's most favourite choice were categorised as (Q13): helps with learning and revision $(N=77)$, convenient $(N=14)$, better than lectures, e.g., no distractions, interactive, more interesting $(N=10)$, blank $(N=7)$, guidance (from students and lecturers; $N=7)$, feedback $(N=3)$, prefer traditional lectures $(N=2)$, time effective $(N=1)$, and not sure $(N=1)$. Chat rooms were the least favourite option (Figure 7), possibly since these "campus-based" students already have existing peer interactions rather than with learners on fully online courses who can feel disengaged (Savvidou, 2013). The term discussion group rather than chat room, however, may have produced a better score.

Q17 asked whether students would prefer to have all/the majority of lectures as video lectures, with the prompt that students could download/watch at own pace and convenience, or to follow the traditional style of learning (coming to lectures). Interestingly, the results were $c a .50: 50(N=63,52 \% ; N=59$, respectively). On reflection, this was probably a poor question since students may have thought that lectures would be completely removed and replaced with videos without understanding/being told the concept of the flipped lecture; i.e., formal lecture viewed online by students in their own time and the allocated lecture timetabled slot arranged to provide a more interactive session, such as going over the video, asking questions and having formative assessments (Bergmann \& Sams, 2012; Tomory \& Waterson, 2015).

Figure 7. Student preferences to staff/author suggestions for enhancing the chemistry VLE (Q12).

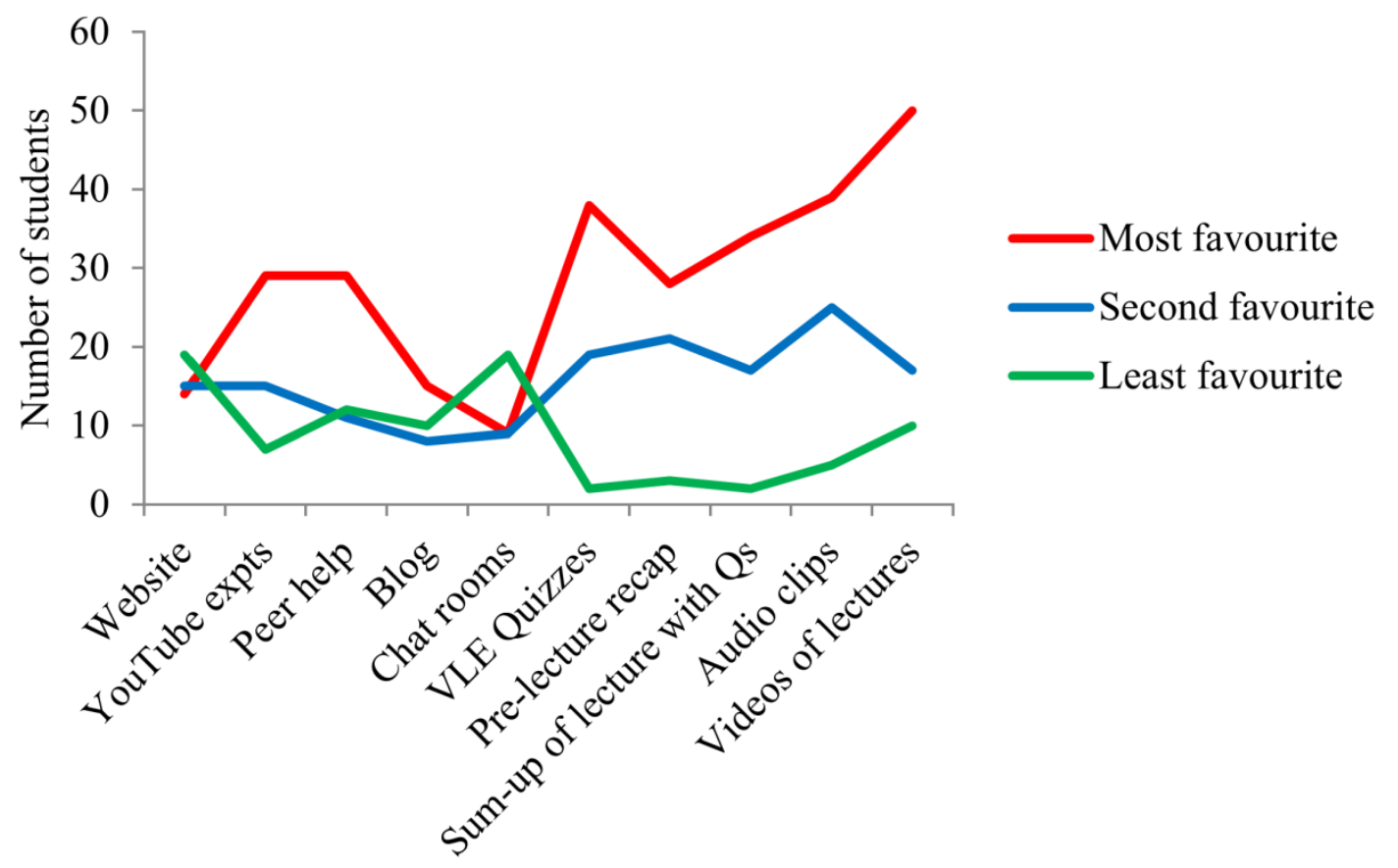

\section{CONCLUSIONS}

This study aimed to investigate undergraduate pharmacy students' perspectives regarding the importance of their learning of chemistry content and how this might be enhanced by 
improvements to the VLE. The pre-university chemistry background experience of the students was also investigated to ascertain the extent to which this may be affecting current perceptions. MPharm students had a wide variation in prior chemistry learning, both theoretically and practically, although this appeared to have no impact on student perceived workload, difficulty and relevance of chemistry in their studies $(p>0.05)$. Perceived difficulty and workload were positively correlated $(p=0.003)$, however, as were pharmacy students 'not seeing the point' of studying chemistry with perceived difficulty $(p=0.001)$, suggesting areas for intervention. Most pharmacy students $(89 \%)$ said studying chemistry was important, especially when the relevance could be easily identified, and were able to provide appropriate reasons for needing to study the subject. Students rated chemistry-related units with the same level of enjoyment as their biologycentred counterparts $(p>0.05)$, although pharmacy practice elements were deemed more enjoyable $(p<0.0001)$, presumably due to the perceived direct relevance for their future careers. Pharmacy students welcomed more laboratory practical sessions, although under less stressful conditions, and wider use of audience response systems in lectures (in years 1 to 3). Students also welcomed more VLE content, which they access mainly via laptops and smart phones, especially in the form of video lectures and formative assessments (quizzes). These provide, respectively, the ability to review content and gauge current learning (feedback), which are in alignment with evidence-based practices (Hattie, 2009). This study represents a snapshot of the student opinions in one pharmacy education school in the UK and clearly the situation may well be different elsewhere (Hall et al., 2015). It is likely, however, that similar problems associated with making pure science subjects relevant to vocational degree programmes will be of universal interest.

\section{ACKNOWLEDGEMENTS}

We thank the MPharm students for participating in this research for completing questionnaires.

\section{REFERENCES}

Alsharif, N. Z., Destache, C. J., \& Roche, V. F. (1999). Teaching medicinal chemistry to meet outcome objectives for pharmacy students. American Journal of Pharmacy Education, 63(1), 34-40.

Barth-Cohen, L. A., Smith, M. K., Capps, D. K., Lewin, J. D., Shemwell, J. T., \& Stetzer, M. R. (2016). What are middle school students talking about during clicker questions? Characterizing small-group conversations mediated by classroom response systems. Journal of Science Education and Technology, 25(1), 50-61.

Bergmann, J., \& Sams, A. (2012). Flip Your Classroom: Reach Every Student in Every Class Every Day. Arlington: International Society for Technology in Education (ISTE). Retrieved from https://www.iste.org/resources/product?ID=2285. ISBN 9781564843159

Bonk, C. J., \& Graham, C. R. (2006). The Handbook of Blended Learning Environments: Global Perspectives, Local Designs. San Francisco: Jossey-Bass/Pfeiffer.

Chickering, A. W., \& Gamson, Z. F. (1987). Seven principles for good practice in undergraduate education. American Association Higher Education Bulletin, 39(7), 3-7.

Cotes, S., \& Cotua, J. (2014). Using audience response systems during interactive lectures to promote active learning and conceptual understanding of stoichiometry. Journal of Chemical Education, 91, 673-677. 
Faruk Khan, M. O., Deimling, M. J., \& Philip, A. (2011). Medicinal chemistry and the pharmacy curriculum. American Journal of Pharmacy Education, 75(8), Article $161,1-10$.

General Pharmaceutical Council. (2014). Approval process for education and training providers. $\quad$ Retrieved from http://www.pharmacyregulation.org/education/approval-courses. (August 9, 2017)

Hall, M., Hanna, L.-A., Hanna, A., \& Hall. K. (2015). Associations between achievement goal orientations and academic performance among students at a UK pharmacy school. American Journal of Pharmacy Education, 79(5), Article 64, 1-7.

Hattie, J. A. C. (2009). Visible Learning. A Synthesis of Over 800 Meta-analyses Relating to Achievement. London: Routledge.

Jesson, J. K., Langley, C. A., Wilson, K. A., \& Hatfield, K. (2006). Science or practice? UK undergraduate experiences and attitudes to the MPharm degree. Pharmacy World and Science, 28(5), 278-283.

Prescott, J., Wilson, S. E., \& Wan, K. W. (2014). Pharmacy students' perceptions of natural science and mathematics subjects. American Journal of Pharmacy Education, 78(6), Article 118, 1-5.

Roche, V. F., Davis, P. J., Pankaskie, M. C., Currie, B. L., Roche, E. B., Sindelar, R. D., Wynn, J. E., Zito, S. W. (2000). The status of chemistry content in the professional pharmacy curriculum: Results of a national survey. American Journal of Pharmacy Education, 64(3), 239-250.

Roche, V. F., \& Alsharif, N. Z. (2002). Stayin' alive: advancing medicinal chemistry by enhancing student responsibility for learning. American Journal of Pharmacy Education, 66(3), 319-328.

Savvidou, C. (2013). 'Thanks for sharing your story': the role of the teacher in facilitating social presence in online discussion. Technology, Pedagogy and Education, 22(2), 193-211.

Stokes, G., \& Whiteside, D. (1984). One Brain: Dyslexic Learning Correction and Brain Integration. Burbank, CA: Three In One Concepts.

Tomory, A., \& Watson, S. L. (2015). Flipped classrooms for advanced science courses. Journal of Science Education and Technology, 24(6), 875-888. 